\title{
Optimasi kekuatan tarik komposit polyester diperkuat serat sisal dengan filler serbuk gergaji kayu sengon menggunakan metode respon surface
}

\section{IDK. Okariawan*, M. Fajar, S. Hidayatullah}

Teknik Mesin, Fakultas Teknik, Universitas Mataram, Jl. Majapahit No. 62 Mataram, NTB, 83125, Indonesia. Telpon. (0370) 636126, Fax. (0370) 636523

*Email: okateknikunram@yahoo.com

\section{ARTICLE INFO \\ Article history: \\ Received 24 February 2016 \\ Accepted 24 September 2016. \\ Available online 30 December 2016}

Keywords:

Composite

Sisal fiber

Sengon sawdust filler

Respon surface method

\begin{abstract}
Composite is an engineering material, which is made from combination of two or more different materials into a new material with new properties. The aim of this research is to investigate optimum composition of sisal fiber reinforced sawdust sengon filled polyester composites on the tensile strength using respon surface methodology. The testing of tensile strength is based on ASTM D 3039 standard. It has dimension $6 \mathrm{~mm}$ in thick, $25 \mathrm{~mm}$ in width and $340 \mathrm{~mm}$ in length. The composites are made by using compaction method. The volume fraction of sisal fiber is $25 \%, 30 \%$ $35 \%, 40 \%$ and $45 \%$. The ratio matrik with filler is varied 5 , 10, 15, 20 and 25. The fiber length is $90 \mathrm{~mm}$ and the direction of fiber orientation is random. The results shows that the respon surface methodology capable to search value of independent variables to give optimum values of tensile strength. The application of respon surface methodology for the research optimation composition of sisal fiber reinforced sawdust sengon filled polyester composites on the tensile strength showed that the optimum value of tensile strength response could be achieved at volume fraction of sisal fiber $38,6565 \%$ and ratio matrik with filler 24,601 .
\end{abstract}

\section{PENDAHULUAN}

Seiring dengan kemajuan teknologi rekayasa material bahan otomotif, telah banyak dikembangkan model bahan komposit. Pengembangan bahan komposit terus dilakukan untuk menjawab kebutuhan akan bahan-bahan dengan sifat-sifat yang diinginkan. Salah satunya adalah bahan komposit polymer. Komposit merupakan gabungan dari dua atau lebih bahan yang berbeda yang digabung menjadi satu secara makroskopis. Bahan komposit pada umumnya terdiri dari dua unsur yaitu serat (fiber) sebagai bahan pengisi dan bahan pengikat serat tersebut yang disebut matrik.

Komposit dari bahan serat (fibrous composites) terus diteliti dan dikembangkan guna menjadi bahan alternativ pengganti bahan logam, hal ini disebabkan karena sifat dari komposit serat yang kuat dan mempunyai berat yang lebih ringan dibandingkan dengan logam. Serat alam 
merupakan alternatif penguat komposit untuk berbagai komposit polymer karena keunggulannya dibanding serat sintetis. Serat alam mudah didapatkan dengan harga yang murah, mudah diproses, densitasnya rendah, ramah lingkungan, dan dapat diuraikan secara boilogi. Akhir-akhir ini, pemanfaatan serat alam sebagai penguat komposit telah diaplikasikan secara komersial di berbagai bidang seperti bidang otomotif dan konstruksi. Serat yang dihasilkan dari daun sisal tersebut digunakan sebagai tali, benang, karpet, dan kerajinan karena kekuatannya yang baik, tahan lama, stretch, dan afinitas terhadap zat warna baik. Saat ini pemanfaatan utama sisal terbatas pada bidang kelautan dan pertanian. Aplikasi serat sisal antara lain pada pembuatan benang, tali, bahan pelapis, tikar, jala ikan, serta barang kerajinan seperti dompet, hiasan dinding, meja dan karpet. Aplikasi terbaru serat sisal yaitu pada pembuatan panel atap yang kuat dan murah serta tahan api.

Sementara itu pemanfaatan limbah serbuk gergaji kayu dewasa ini belum terlalu dilirik oleh masyarakat, terutama para pemilik industri pemotongan kayu. Sebagian besar serbuk gergaji kayu dibiarkan menumpuk begitu saja dan dibakar percuma oleh masyarakat, tanpa melihat nilai ekonomis yang bias didapatkan dari pemanfaatan limbah kayu tesebut. Namun seiring meluasnya ruang lingkup ilmu pengetahuan dibidang material dan bahan, kini limbah serbuk gergaji kayu tersebut mulai dimanfaatkan sebagai material pencampur komposit. Salah satu limbah serbuk gergaji kayu yaitu kayu sengon.

Pratama et al. (2014) meneliti pegaruh perlakuan alkali, fraksi volume serat, dan panjang serat terhadap kekuatan tarik komposit serat sabut kelapa-polyester dengan fraksi volume serat yaitu $35 \%$, 40\%, dan 45\%. Hasil penelitiannya pada variasi fraksi volume menunjukkan bahwa semakin besar fraksi volume serat semakin kecil nilai kuat tariknya. Fraksi volume serat yang terlalu besar menurunkan kekuatan tarik karena semakin banyak serat pada komposit maka komposisi serat akan lebih padat sehingga mempersulit resin/matrik untuk masuk kesela-sela serat secara sempurna, sehingga berakibat resin tidak dapat mengikat seluruh bagian serat secara sempurna. Dengan fraksi volume serat 35\% mempunyai nilai rata-rata kuat tarik tertinggi sebesar 16,42 MPa.

Dari kajian beberapa jurnal, belum didapat komposisi optimum dari komposit polyester sehingga perlu dilakukan penelitian untuk mendapatkan komposisi optimum dengan menggunakan metode respon surface.

Pengambilan serat daun sisal pada umumnya dilakukan pada usia tanaman berkisar antara 1 sampai 1,5 tahun. Serat yang berasal dari daun sisal yang masih muda pada umumnya tidak panjang dan kurang kuat. Sedang serat yang dihasilkan dari tanaman sisal yang terlalu tua, terutama tanaman yang pertumbuhannya di alam terbuka dengan intensitas matahari cukup tinggi tanpa pelindung akan menghasilkan serat yang pendek kasar dan getas atau rapuh Doraiswarmy (1993). Sisal (Agave sisalana) merupakan tanaman yang hanya tumbuh di daerah tropis dan subtropis. Serat sisal diekstraksi dari daunnya. Satu tanaman sisal memproduksi sekitar 200-250 daun dimana satu daun terdiri dari 1000-1200 bundel serat. Dari $100 \mathrm{~kg}$ daun sisal, serat yang dihasilkan dari daun tersebut sekitar 3-4 kg (rendemen 3-4\%). Berdasarkan berat kering, serat sisal terdiri dari 54-66\% selulosa, 12-17\% hemiselulosa, 7-14\% lignin, $1 \%$ pectin, dan $1-7 \%$ abu. Serat sisal berupa bundle mempunyai panjang 1-1,5 m dan diameter 100-300 $\mu \mathrm{m}$. Sisal mempunyai serat yang keras, kasar, sangat kuat dan berwarna putih kekuningan. Kerapatan serat $1,3-1,5 \mathrm{~g} / \mathrm{cm}^{2}$, kekuatan tarik serat 510-635 $\mathrm{N} / \mathrm{mm}^{2}$ dan modulus tarik 9,4-22,0 Gpa Dahal et al.(2003).

Kekuatan dan durabilitas komposit yang terbuat dari serat alam dan plastik sangat ditentukan oleh ikatan antara penguat dan matriknya, untuk itu diperlukan perlakuan permukaan pada serat alam. Diharjo (2005) telah meneliti pengaruh lama perlakuan alkali terhadap kekuatan tarik komposit serat kenaf dengan lama perlakuan 0, 2, 4, 6 dan 8 jam. Berdasarkan hasil penelitiannya dapat disimpulkan bahwa dengan perlakuan alkali serat alam selama 2 jam menghasilkan kekuatan tarik dan modulus elastis paling tinggi. Kekuatan komposit yang diperkuat serat tanpa perlakuan dan dengan perlakuan alkali masing-masing adalah 28,38 MPa dan 31,57 $\mathrm{MPa}$, hasil tersebut menunjukan bahwa serat dengan perlakuan alkali $(5 \% \quad \mathrm{NaOH})$ mampu meningkatkan kekuatan bending komposit tersebut Jamasri et al.(2006).

Hasil penelitian dari Mahmuda et al. (2013) telah meneliti pengaruh panjang serat terhadap kekuatan tarik komposit berpenguat serat ijuk dengan matrik epoxy, dengan variasi panjang serat $30 \mathrm{~mm}, 60 \mathrm{~mm}$, dan $90 \mathrm{~mm}$. Hasil penelitian menunjukkan bahwa kekuatan tarik dan regangan tertinggi dicapai pada komposit dengan panjang serat $90 \mathrm{~mm}$. Kekuatan tarik 
yang didapat sebesar $36,37 \mathrm{MPa}$ dan regangan sebesar 9,34 \%.

Pratama et al. (2014) meneliti pegaruh perlakuan alkali, fraksi volume serat, dan panjang serat terhadap kekuatan tarik komposit serat sabut kelapa-polyester dengan fraksi volume serat yaitu 35\%, 40\%, dan $45 \%$. Hasil penelitiannya pada variasi fraksi volume menunjukkan bahwa semakin besar fraksi volume serat semakin kecil nilai kuat tariknya. Fraksi volume serat yang terlalu besar menurunkan kekuatan tarik karena semakin banyak serat pada komposit maka komposisi serat akan lebih padat sehingga mempersulit resin/matrik untuk masuk kesela-sela serat secara sempurna, sehingga berakibat resin tidak dapat mengikat seluruh bagian serat secara sempurna. Dengan fraksi volume serat $35 \%$ mempunyai nilai rata-rata kuat tarik tertinggi sebesar 16,42 MPa. Prasetyo (2007) telah meneliti pengaruh fraksi volume serat aren (arenga pinata) dengan matrik polyester terhadap kekuatan bending dan tarik. Hasil penelitian menunjukkan bahwa kekuatan tarik maksimal dimiliki oleh komposit dengan fraksi volume $40 \%$ yang besarnya $1,4 \mathrm{~kg} / \mathrm{mm}^{2}$. Sedangkan flexural modulus dan flexural strength tertinggi terjadi pada komposit dengan fraksi volume $40 \%$, yang besarnya adalah $129,4 \mathrm{~kg} / \mathrm{mm}^{2}$ dan $6,4 \mathrm{~kg} / \mathrm{mm}^{2}$.

Variasi fraksi volume serat mempengaruhi kekuatan tarik dan kekuatan impak komposit, dimana kekuatan tarik tertinggi diperoleh pada komposit dengan fraksi volume serat $70 \%$ yaitu $5,3 \mathrm{kgf} / \mathrm{mm}^{2}$. Dimana terlihat terjadi peningkatan tegangan tarik komposit yang seiring dengan pertambahan fraksi volume serat yaitu $0 \%, 10 \%$, $20 \%, 30 \%, 40 \%, 50 \%, 60 \%$, dan $70 \%$. Semakin tinggi fraksi volume serat maka tegangan tarik juga ikut meningkat. Sampai pada fraksi volume serat tertinggi, komposit tidak mengalami penurunan kekuatan tarik. Ini menunjukkan bahwa matrik masih bekerja baik menerima beban dan diteruskan ke serat.

Penelitian mengenai komposit telah banyak dilakukan. Salah satunya fraksi volume dari filler material komposit akan mempengaruhi sifat mekanik dari material komposit. Azwar (2009) meneliti mengenai perilaku mekanik komposit polyester yang diperkuat dengan prtikel serbuk kayu keras dan lunak. Dengan perbandingan fraksi volume antara volume filler dengan volume matrik dengan rasio $10 \%, 15 \%$ dan $20 \%$. Hasil pengujian menunjukkan komposit dengan filler dari jenis serbuk kayu lunak dengan komposisi dan ukuran filler $10 \%$ fraksi volume dan $0.4 \mathrm{~mm}$ mengalami peningkatan sifat mekanik yang paling bagus yaitu $0,0722 \mathrm{kN} / \mathrm{mm}^{2}$ untuk filler kayu lunak dan $0,0657 \mathrm{kN} / \mathrm{mm}^{2}$ untuk filler kayu keras.

Hasil penelitian Nuryanti and Salimy (2008), aplikasi metode permukaan respon pada eksperimen penumbuhan kristal menunjukkan bahwa nilai respon penumbuhan kristal optimal diperoleh pada suhu $(x 1)=807,165^{\circ} \mathrm{C}$, tekanan $(x 2)=2,336$ bar dan $\mathrm{PH}(\mathrm{x} 3)=11,5169$. Sementara nilai respon penumbuhan kristal optimal yang diperoleh adalah sebesar 106,0022 gram. Dan dapat disimpulkan bahwa metode permukaan respon dapat digunakan untuk mengetahui nilai variabel-variabel independen yang menyebabkan nilai variabel respon suatu proses eksperimen kimia menjadi optimal.

Kata komposit merupakan kata sifat yang berarti susunan atau gabungan. Komposit berasal dari kata "to compose" yang berarti menyusun atau menggabungkan. Jadi secara sederhana bahan komposit berarti bahan gabungan dari dua atau lebih bahan yang berlainan. Dalam hal ini gabungan bahan ada dua macam yaitu (Jones, 1999): 1). Gabungan secara makro yaitu dibedakan secara visual, penggabungan lebih secara fisis dan mekanis, dapat dipisahkan secara fisis dan mekanis. 2). Gabungan secara mikro yaitu tidak dapat dibedakan secara visual, penggabungan ini lebih secara kimia, sulit dipisahkan, tetapi dapat dilakukan secara kimia.

\section{Metode Respon Surface}

Response Surface Methodology (RSM) atau Metode Permukaan Respon adalah sekumpulan metode-metode matematika dan statistika yang digunakan dalam pemodelan dan analisis, yang bertujuan untuk melihat pengaruh beberapa variabel kuantitatif terhadap suatu variabel respon dan untuk mengoptimalkan variabel respon tersebut. Sebagai contoh, akan dicari level-level dari suhu $\left(x_{1}\right)$ dan tekanan $\left(x_{2}\right)$ yang dapat mengoptimalkan suatu hasil produksi $(y)$. Hubungan variabel-variabel tersebut dapat dituliskan dalam sebuah persamaan sebagai berikut :

$y=\left(x_{1}+x_{2}\right)+\varepsilon$

Dimana $\varepsilon_{i}$ merupakan error pengamatan pada respon $y$. Jika nilai harapan respon dituliskan $(y)=\left(x_{1}+x_{2}\right)=\eta, \quad$ maka $\quad \eta=f\left(x_{1}+x_{2}\right)$ merepresentasikan sebuah permukaan yang disebut permukaan respon.

\section{Karakteristik permukaan respon}

Misalkan ingin didapatkan nilai $x_{1}, x_{2}, \ldots, x k$ yang mengoptimalkan respon yang diprediksikan. 
Jika nilai-nilai optimal ini ada, maka y pada persamaan (1) merupakan himpunan yang beranggotakan $x_{1}, x_{2}, \ldots, x k$ sedemikian sehingga turunan parsialnya:

$\frac{\partial \hat{y}}{\partial x_{1}}-\frac{\partial \hat{y}}{\partial x_{2}}-\cdots \cdots-\frac{\partial \hat{y}}{\partial x_{k}}$

Dalam notasi matriks, persamaan (2) dapat dinyatakan sebagai:

$\hat{y}=\hat{\beta} 0+\boldsymbol{x}^{\prime} \boldsymbol{b}+\boldsymbol{x}^{\prime} \boldsymbol{B} \boldsymbol{x}$

dimana, $\hat{\beta}_{i j}$ dan elemen-elemen segitiga atasnya adalah $1 / 2$ dari koefisien kuadratik campuran $\left(\hat{\beta}_{i j}, i \neq j\right)$. Turunan dari $\hat{y}$ terhadap vektor $x$ adalah sama dengan 0 , sehingga dinyatakan dengan:

$\frac{\partial \hat{y}}{\partial x}=\mathrm{b}+2 \mathrm{Bx}$

Titik-titik stasioner yang merupakan solusi dari persamaan diatas, adalah:

$$
x_{0}=-\frac{1}{2} \boldsymbol{B}^{-1} b
$$

di mana $x_{0}^{T}=(x 1.0, x 2.0, \ldots, x k .0)$. Substitusi

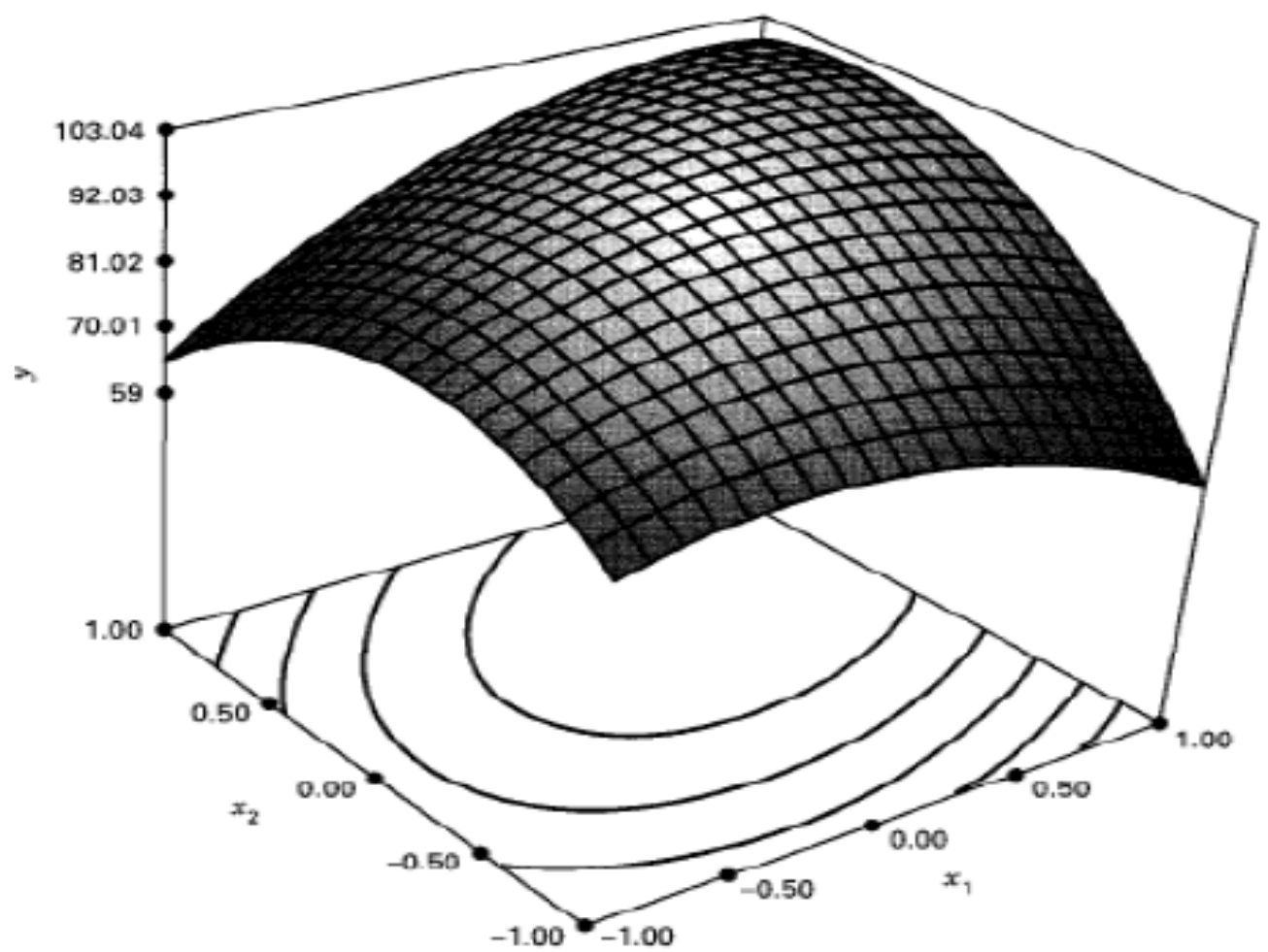

(a) Response surface

Gambar 1. Ilustrasi permukaan respon maksimum

$$
\boldsymbol{x}^{\prime}=\left[\begin{array}{c}
x_{1} \\
x_{2} \\
\vdots \\
x_{k}
\end{array}\right] \quad \boldsymbol{b}=\left[\begin{array}{c}
\hat{\beta}_{1} \\
\hat{\beta}_{2} \\
\hat{\beta}_{3} \\
\vdots \\
\hat{\beta}_{k}
\end{array}\right] \quad \text { dan } \quad \boldsymbol{B}=\left[\begin{array}{cccc}
\hat{\beta}_{11} & \hat{\beta}_{12} / 2 & \cdots & \hat{\beta}_{1 k} / 2 \\
\hat{\beta}_{12} / 2 & \hat{\beta}_{22} & \cdots & \hat{\beta}_{1 k} / 2 \\
\vdots & \vdots & \ddots & \vdots \\
\hat{\beta}_{1 k} / 2 & \hat{\beta}_{1 k} / 2 & \cdots & \hat{\beta}_{k k}
\end{array}\right]
$$

b merupakan vektor koefisien regresi orde pertama, sedangkan $B$ adalah matriks orde kedua berukuran $\mathrm{k}$ x $\mathrm{k}$ yang elemen diagonal utamanya merupakan koefisien kuadratik murni persamaan (5) ke persamaan (3) diperoleh nilai respon optimal yang diprediksikan terjadi pada titik-titik stasioner, yaitu:

$y=\beta_{0}+\frac{1}{2} x_{0}^{2} b$

Karakteristik permukaan respon digunakan untuk menentukan jenis titik stasioner apakah maksimum dan minimum. 
Titik stasioner dapat diidentifikasi dengan mentransformasikan fungsi respon dari titik asal $x$ $(0,0, \ldots, 0)$ ke titik stasioner $x_{0}$ dan sekaligus respon adalah hal yang sangat penting. Berikut ada beberapa kriteria dalam pemilihan rancangan percobaan yang sesuai untuk metode

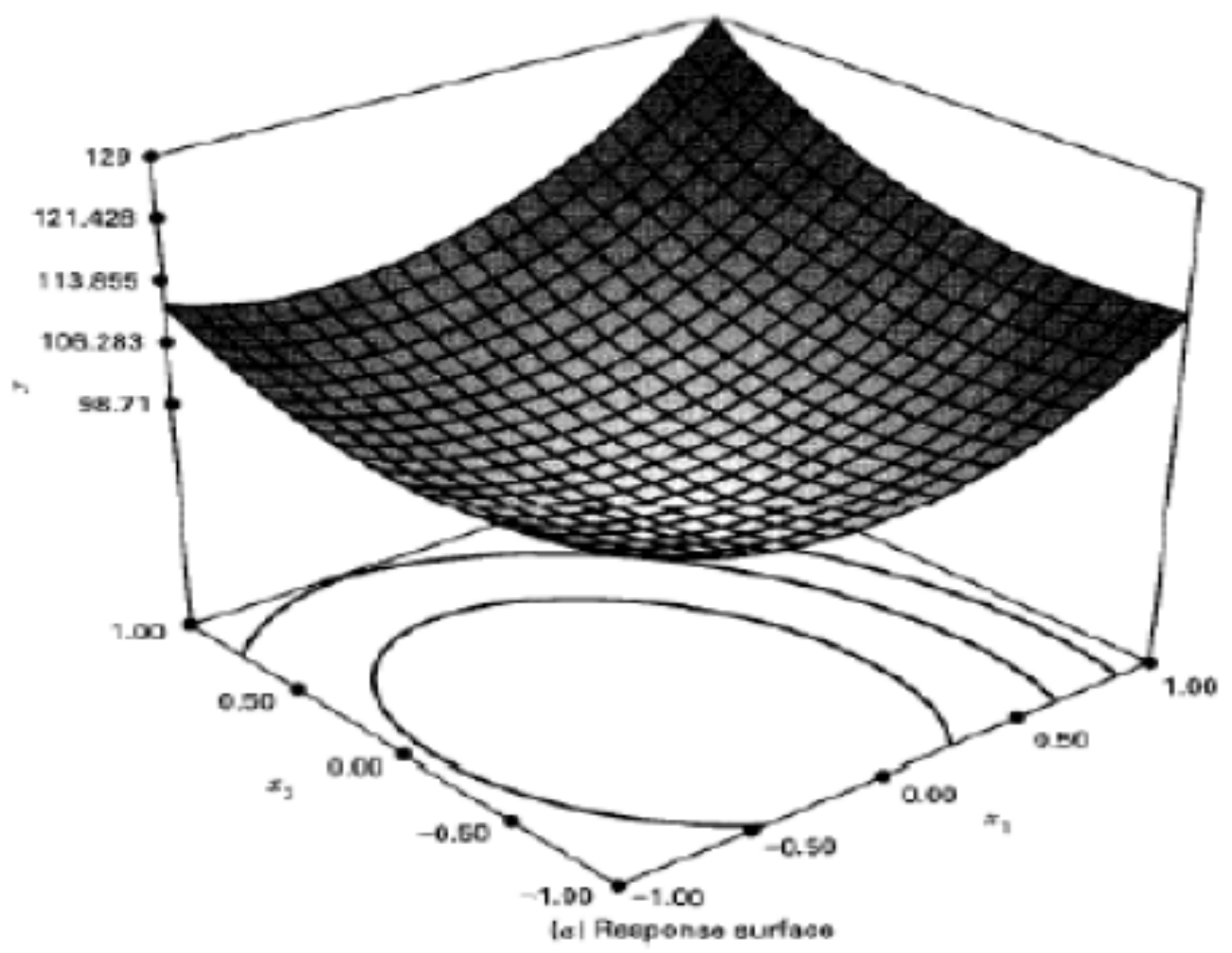

Gambar 2. Ilustrasi permukaan respon minimum

merotasikan sumbu koordinatnya, sehingga dihasilkan fungsi respon sebagai berikut:

$\hat{y}=\hat{y}_{0}+\lambda_{1} w_{1}^{2}$ । $\lambda_{2} w_{2}^{2}$ । । $\lambda_{k} w_{k}^{2}$

dengan wi adalah variabel independen baru hasil transformasi, $y_{0}$ merupakan harga taksiran $y$ pada titik stasioner $x_{0}, \lambda i$ menyatakan konstanta yang merupakan eigen value dari matrik $\boldsymbol{B}, i=$ $1,2, \ldots, k$.

Karakteristik dari permukaan respon ditentukan oleh harga $\lambda i$. Jika nilainya semua positif maka $x_{r}$ adalah titik minimum, sedangkan jika semua negatif maka $x_{0}$ adalah titik maksimum, jika harganya berbeda tanda diantara harga $\lambda i$, maka $x_{\square}$ merupakan titik pelana.

\section{Rancangan yang sesuai untuk permukaan respon}

Pemilihan rancangan percobaan yang sesuai beserta analisisnya untuk permukaan permukaan respon:

1. Memberikan gambaran distribusi dan informasi yang jelas berdasarkan data pada seluruh daerah yang difokuskan

2. Memungkinkan untuk mencari model yang memenuhi kelayakan model

3. Memungkinkan untuk membuat blok-blok dalam percobaan

4. Memungkinkan untuk membuat rancangan-rancangan yang mempunyai orde lebih tinggi

5. Memberikan pendugaan error dalam rancangan

6. Memberikan pendugaan koefisien model yang tepat

7. Memberikan pendugaan varians yang baik

8. Bersifat robust terhadap outliers maupun data hilang

9. Tidak membutuhkan unit percobaan yang besar 
10. Tidak membutuhkan terlalu banyak level dalam variabel independen

11. Memberikan kemudahan dalam perhitungan parameter model kadangkadang, kriteria di atas saling tidak mendukung, tetapi pemilihan rancangan harus tetap dilakukan sebaik mungkin.

\section{METODE PENELITIAN}

Bahan dan Alat Penelitian

Adapun bahan yang digunakan dalam pembuatan komposit serat sisal adalah Resin polyester, Serat sisal dan katalist. Sedangkan alat yang digunakan yaitu cetakan baja, alat pengepres dan alat uji tarik universal tensile a. Alat dan bahan dipersiapkan terlebih dahulu sesuai dengan komposisi komposit dengan kandungan serat 25\%,30\%, 35\%, 40\% dan $45 \%$ dengan perbandingan volume matrik dengan filler 5, 10, 15, 20 dan 25 dengan panjang serat $90 \mathrm{~mm}$.

b. Siapkan cetakan berupa baja yang telah dilapisi terlebih dahulu dengan cairan wax, untuk melapisi komposit serat sisal agar tidak menempel pada cetakan.

c. Taruh serat kedalam cetakan dan kemudian taburkan filler

d. Campurkan polyester dan hardener, setelah rata tuangkan cairan pada cetakan hingga merata sampai resin membasahi seluruh

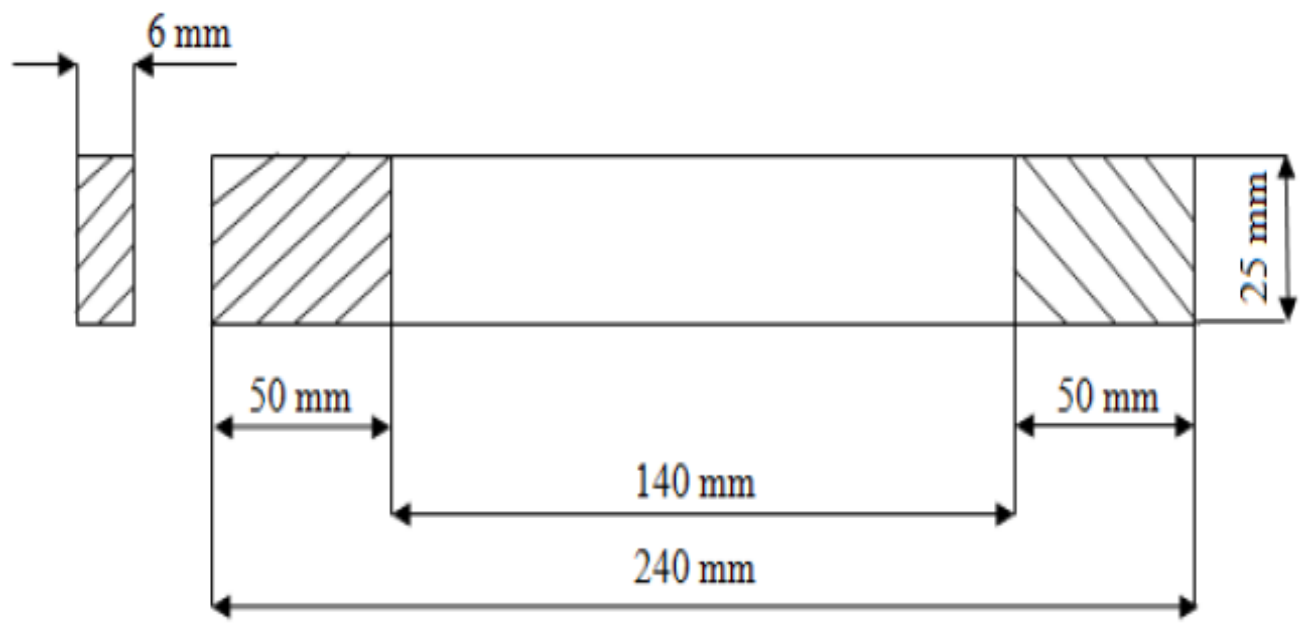

Gambar 3. Spesimen uji tarik

machine (UTM) serta peralatan pendukung lainnya.

\section{Proses Perlakuan Serat Sisal}

Serat sisal yang sudah didapat kemudian direndam dalam larutan $\mathrm{NaOH}$ dengan konsentrasi 5\% (berat) selama 2 jam. Setelah direndam dalam larutan $\mathrm{NaOH}$ serat sisal dicuci dengan menggunakan air PDAM sampai bersih dan dikeringkan di bawah sinar matahari. Kemudian serat sisal dipotong dengan panjang $90 \mathrm{~mm}$.

\section{Pembuatan Komposit Berpenguat Serat Sisal}

Serat yang digunakan adalah serat sisal berupa serat acak. Pembuatan komposit serat sisal ini menggunakan cetakan manual yang terbuat dari baja. Adapun proses pembuatan komposit serat sisal adalah sebagai berikut: serat dan filler .

e. Selanjutnya lapisi bagian atas cetakan dengan kertas transparan agar saat pelepasan spesimen tidak lengket dengan penutup cetakan.

f. Tutup bagian atas cetakan dengan baja dan ditekan dengan alat pengeperes dengan tekanan sebesar $1906 \mathrm{~N} / \mathrm{mm}^{2}$ kemudian diamkan minimal 3 jam atau lebih sampai spesimen mengering.

g. Kemudian spesimen yang telah dicetak difinishing menjadi benda uji yang sesuai dengan standar uji tarik.

\section{Langkah Pengujian}

Uji tarik adalah salah satu uji stress-strain mekanik yang bertujuan untuk mengetahui kekuatan bahan terhadap gaya tarik atau untuk mendapatkan nilai modulus elastisitas komposit 
serat sisal yang digunakan dalam penelitian ini. Pengujian menggunakan alat Universal testing Machine. Dengan bentuk dan dimensi spesimen seperti gambar 3 .

\section{HASIL DAN PEMBAHASAN}

Data-data yang didapat dari hasil pengujian tarik kemudian diolah dengan model matematika meggunakan metode respon surface. Metode respon suface adalah merupakan sekumpulan teknik matematika dan statistika yang berguna untuk menganalisis dan mengoptimalkan model, pada penelitian ini terdapat dua variabel independen yang diperhatikan sebagai variable-variabel yang mempengaruhi kekuatan tarik komposit polyester, yaitu fraksi volume serat $(x 1)$ dan rasio antara matrik dengan filler $(x 2)$. Desain eksperimen yang digunakan adalah desain faktorial dua level $\left(2^{k}\right)$ ditambah dengan Central Composite Design (CCD). Dari hasil pengolahan data menggunakan minitab didapat data eksperimen kekuatan tarik.

Adapun variabel-variabel beserta level dalam penelitian ini meliputi:

1. Variabel respon, yaitu kekuatan tarik.

2. Variabel bebas/faktor yang terdiri dari:

- Fraksi volume serat $\left(x_{1}\right)$, yaitu $25 \%, 30 \%$, $35 \%, 40 \%$ dan $45 \%$

- Rasio matrik dengan filler $\left(\mathrm{x}_{2}\right)$, yaitu 5,10 , 15, 20 dan 25.

Tabel 1. Kode level dengan nilai level

\begin{tabular}{cccc}
\hline Kode level & -1 & 0 & 1 \\
\hline X1 & 35 & 40 & 45 \\
X2 & 10 & 15 & 20 \\
\hline
\end{tabular}

Level-level eksperimen pada masingmasing variabel independen dikodekan sedemikian hingga level rendah berhubungan dengan -1 dan level tinggi berhubungan dengan 1 untuk mempermudah perhitungan. Desain CCD pada eksperimen menggunakan 2 variabel independen, sehingga nilai rotabilitasnya $=\left(2^{2}\right.$ $j^{\frac{1}{4}}=1,4142 \approx 1,414$. Oleh karena itu nilai $\pm 1,414$ termasuk nilai yang digunakan untuk pengkodean.

Setelah dikodekan, maka didapat data kode seperti ditunjukan pada tabel 2. Data pada tabel 2. kemudian diolah dengan menggunakan software Minitab 16.2.4.4 _www.remo-xp.com.

Dari hasil penelitian terhadap pengaruh fraksi volume serat dan rasio matrik dengan filler didapat kekuatan tarik terbesar pada fraksi volume serat $40 \%$ dimana kekuatan tarik meningkat seiring bertambahnya level fraksi volume serat tetapi pada fraksi volume serat $45 \%$ kekuatan tarik menurun, ini dikarenakan resin tidak mampu membasahi serat secara sempurna sehingga ikatan antara resin dan serat menjadi lemah. Sedangkan pada rasio matrik dengan filler 5, 10, 15, 20, dan 25 terhadap kekuatan tarik terus terjadi peningkatan.

Tabel 2. Data pengkodean variabel independen

\begin{tabular}{ccc}
\hline Fv Serat & Rmf & Kekuatan tarik \\
\hline-1 & -1 & 34.58 \\
1 & -1 & 35.52 \\
-1 & -1 & 31.01 \\
1 & -1 & 40.23 \\
-1 & -1 & 27.07 \\
1 & -1 & 35.82 \\
-1 & 1 & 44.05 \\
1 & 1 & 38.18 \\
-1 & 1 & 47.19 \\
1 & 1 & 48.53 \\
-1 & 1 & 52.37 \\
-1.41421 & 0 & 36.72 \\
1.414214 & 0 & 37.89 \\
0 & -1.41421 & 50.47 \\
0 & 1.414214 & 53.79 \\
0 & 0 & 45.08 \\
0 & 0 & 60.33 \\
0 & 0 & 64.79 \\
0 & 0 & 43.75 \\
0 & 0 & 50.82 \\
0 & 0 & 36.73 \\
0 & 0 & 46.84 \\
0 & 0 & 59.29 \\
0 & 0 & 55.53 \\
0 & 0 & 49.44 \\
\hline
\end{tabular}

\section{Optimalisasi Komposisi Komposit Menggunakan Metode Respon Surface}

Dengan model matematika dari respon surface telah mengidentifikasi komposisi optimum dari komposit untuk menghasilkan kekuatan tarik terbaik. Pembuatan komposit dengan variasi fraksi volume serat $(25 \%, 30 \%$, $35 \%$, $40 \%$, dan $45 \%$ ) dan variasi rasio volume filler dengan matrik $(5,10,15,20$ dan 25) yang dapat mempengaruhi kekuatan tarik komposit telah diprediksi menggunakan metode respon.

surface. Contour plot prediksi untuk kekuatan tarik komposit polyester diperkuat serat sisal yaitu seperti pada gambar 4. dan 5 .

Dari gambar 4. terlihat fraksi volume serat yaitu $35 \%, 40 \%$ dan $45 \%$ rmf yaitu 10,15 dan 20 kemudian dari plot optimasi metode respon surface dari kekuatan tarik vs fraksi volume serat, rasio matrik filler, terlihat bahwa nilai kekuatan tarik > 50 berada diantara titik dengan fraksi 
volume serat mulai dari $35 \%$ sampai $40 \%$. Sedangkan nilai kekuatan tarik $>50$, untuk rasio matrik dengan filler berada (akan di dapat) pada titik dengan rasio matrik dan filler mulai dari 15 terus meningkat.
Kekuatan tarik $=51.2600+0.4440 \mathrm{x}_{1}+4.6390 \mathrm{x}_{2}$ $8.8094 \mathrm{x}_{1}^{2}-1.3969 \mathrm{x}_{2}^{2-}$ $2.6976 \mathrm{x}_{1}{ }^{*} \mathrm{x}_{2}$

Kemudian dari model kekuatan tarik tersebut didapat persamaan matrik seperti pada

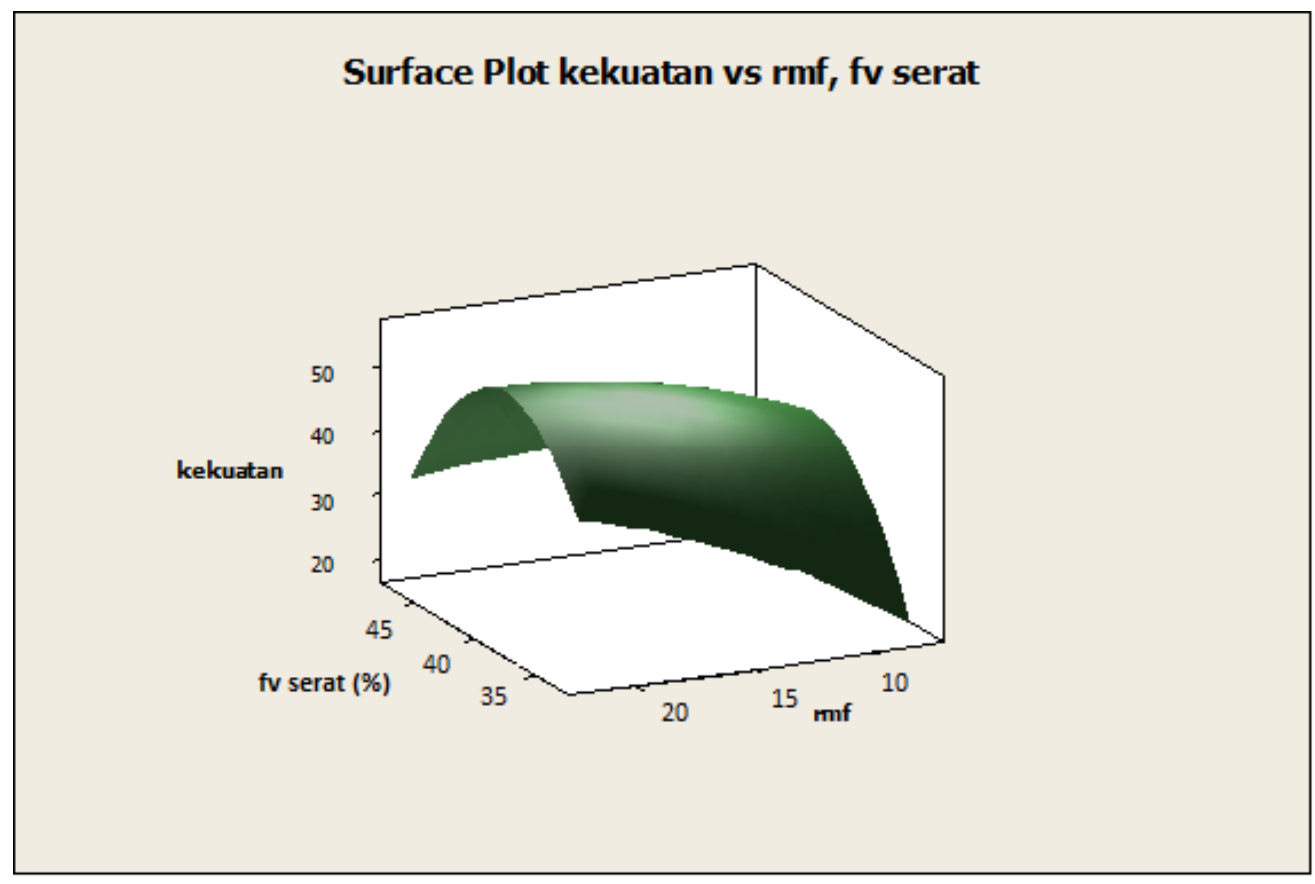

Gambar 5. Plot permukaan respon kekuatan tarik vs fraksi volume serat, rmf

Dari pengamatan visual pada gambar 4 . dan 5. terlihat bahwa variasi fraksi volume optimal terhadap kekuatan tarik didapat pada fraksi volume serat sebesar $40 \%$ sedangkan untuk variasi rasio matrik dengan filler masih mengalami kenaikan dari rasio 10, 15, dan 20.

Dari hasil penelitian terhadap pengaruh fraksi volume serat dan rasio matrik dengan filler didapat kekuatan tarik terbesar pada fraksi volume serat $40 \%$ dimana kekuatan tarik meningkat seiring bertambahnya level fraksi volume serat tetapi pada fraksi volume serat $45 \%$ kekuatan tarik menurun, ini dikarenakan resin tidak mampu membasahi serat secara sempurna sehingga ikatan antara resin dan serat menjadi lemah. Sedangkan pada rasio matrik dengan filler $5,10,15,20$, dan 25 terhadap kekuatan tarik terus terjadi peningkatan.

Mencari titik optimum menggunakan model kuadratik yang telah dinyatakan sesuai dengan data dan pengkodean sebagaimana model kekuatan tarik yang diperoleh dari pengujian regresi yaitu: persamaan berikut:

$$
\begin{aligned}
& \mathrm{b}=\left[\begin{array}{l}
\hat{\beta}_{1} \\
\hat{\beta}_{2}
\end{array}\right], \quad \mathrm{B}=\left[\begin{array}{cc}
\hat{\beta}_{11} & \hat{\beta}_{12} / 2 \\
\hat{\beta}_{12} / 2 & \hat{\beta}_{22}
\end{array}\right] \\
& \text { b }=\left[\begin{array}{l}
0.4440 \\
4.6390
\end{array}\right] \text {, } \\
& \mathrm{B}-\left[\begin{array}{ll}
-8.8094 & -1.3490 \\
-1.3490 & -1.3969
\end{array}\right] \\
& \operatorname{det} \mathrm{B}=\hat{\beta}_{11} \times \hat{\beta}_{22}-\hat{\beta}_{12} / 2 \times \hat{\beta}_{12} / 2 \\
& =12.3058-1.8196 \\
& =10.4862 \\
& \mathrm{~B}^{-1}=\frac{1}{\operatorname{det} \mathrm{B}}\left[\begin{array}{cc}
-1.3969 & 1.3490 \\
1.3490 & -8.8094
\end{array}\right] \\
& =\left[\begin{array}{cc}
-0.1332 & 0.1286 \\
0.1286 & -0.8401
\end{array}\right]
\end{aligned}
$$

Dari matrik di atas dimasukan ke dalam persamaan (5) sebagai berikut:

$$
\begin{aligned}
& x_{0}=-\frac{1}{2} \boldsymbol{B}^{-1} b \\
& x_{0}--\frac{1}{2}\left[\begin{array}{cc}
-0.1332 & 0.1286 \\
0.1286 & -0.8401
\end{array}\right]\left[\begin{array}{l}
0.4440 \\
4.6390
\end{array}\right]
\end{aligned}
$$




$$
\begin{aligned}
& x_{0}=-\frac{1}{2}\left[\begin{array}{c}
-0.0591+0.5965 \\
0.0571-3.8972
\end{array}\right] \\
& x_{0}--\frac{1}{2}\left[\begin{array}{c}
0.5374 \\
-3.8401
\end{array}\right]
\end{aligned}
$$

Sehingga didapat matrik $x_{0}$ yaitu:

$$
x_{0}=\left[\begin{array}{c}
-0.2687 \\
1.9201
\end{array}\right]
$$

Selanjutnya matrik $x_{0}$ digunakan untuk mencari nilai titik optimal pada rumus di bawah ini:

Dimana,

$$
x_{1}=-0.2687 ; \quad x_{2}=1.9201
$$

- Untuk optimum fraksi volume serat

$$
\begin{aligned}
x_{1} & =\frac{\text { Nilai optimum fvs }- \text { middle range }}{\text { Interval }} \\
-0.2687 & =\frac{\text { Nilai optimum fvs }-40}{5} \\
\text { Nilai optimum tvs } & =38.6
\end{aligned}
$$

- Untuk optimum $R m f$

$$
\begin{aligned}
& x_{2}=\frac{\text { Nilai motimm rmf- middle ram } g^{g}}{\text { Inlervui }} \\
& 1.9201=\frac{\text { Nilai optimum fvs }-15}{5} \\
& \text { Nilai optimum } \mathrm{rmf}=24.6
\end{aligned}
$$

Dari perhitungan persamaan (3) dan (5) didapatkan titik optimal yang bisa menghasilkan respon semaksimal mungkin yang sesuai dengan harapan adalah dengan menggunakan fraksi volume serat $38.6 \%$ dan rasio matrik dengan filler 24.6.

Kemudian nilai $\mathrm{x}_{1}$ dan $\mathrm{x}_{2}$ dimasukkan ke dalam model matematika kuadratik kekuatan tarik sebagai berikut didapat

Nilai kekuatan tarik dari model yang sudah

Kekuatan tarik $=51.2600+0.4440 \mathrm{x}_{1}+4.6390 \mathrm{x}_{2}-$

$$
\begin{aligned}
& 8.8094 \mathrm{x}_{1}{ }^{2-} 1.3969 \mathrm{x}_{2}{ }^{2-} \\
& 2.6976 \mathrm{x}_{1}{ }^{*} \mathrm{x}_{2} \\
= & 51.2600+0.4440(-0.2687)+ \\
& 4.6390(1.9207)- \\
& 8.8094(-0.2687)^{2-} \\
& 1.3969(1.9207)^{2-} \\
& 2.6976\left(-0.2687^{*} 1.9207\right) \\
= & 55.65 \mathrm{~N} / \mathrm{mm}^{2}
\end{aligned}
$$

Sedangkan hasil pengujian tarik dengan nilai titik optimal yaitu menggunakan fraksi volume serat $38.6 \%$ dan rasio matrik dengan filler 24.6 didapat kekuatan tarik seperti pada tabel 3 .
Nilai optimal berdasarkan metode respon surface dibandingkan dengan hasil eksperimen pada fraksi volume serat $38.6 \%$ dan rasio matrik filler 24.6 terdapat perbedaan sebesar $0.5 \%$. Perbedaan ini dikarenakan model kuadratik untuk menduga kekuatan tarik terdapat error yaitu sebesar $42.18 \%$.

Tabel 3. Nilai kekuatan tarik optimal setelah di uji kekuatan kekuatan tarik rata-rata

58.4

54.25

$55.37 \pm 2.65$

53.46

\section{KESIMPULAN}

Dari hasil peneltian, pengujian dan pembahasan hasil uji yang telah dilakukan maka dapat ditarik kesimpulan sebagai berikut :

1. Nilai optimal kekuatan tarik tercapai pada pada fraksi volume serat $38.6 \%$ dan rasio matrik dengan filler 24.6.

2. Dengan metode permukaan respon dapat digunakan untuk mengetahui nilai variabelvariabel independen yang menyebabkan nilai variabel respon kekuatan tarik menjadi optimal.

3. Dengan pengujian langsung pada kondisi optimal tersebut terdapat perbedaan sebesar $0.5 \%$

\section{DAFTAR PUSTAKA}

ASTM, 2006, Standards and Literature References for Composite Materials, 2d ed., American Society for Testing and Materials, Philadelphia, P.,A.

Azwar., 2009, Study perilaku mekanik komposit berbasis polyester yang diperkuat dengan partikel serbuk kayu keras dan lunak, Jurnal Reaksi, Vol. 17, No. 16.

Dahal K.R., Utomo B.I., Brink M., 2003, Agave sisalana perrine, Plant Resources Of South-East Asia, No. 17, Fibre Plants.

Diharjo K., 2005, Pengaruh perlakuan alkali terhadap sifat tarik bahan komposit serat rami-polyester, Jurnal Teknik Mesin Fakultas Teknik Universitas Sebelas Maret, Surakarta.

Doraiswarmy, 1993, Pineapple leaf fibers, Textile Progress, Vol. 24, No. 1, Textile Institute.

Jamasri, Diharjo K., Handiko G.W., 2006, Studi perlakuan alkali dan tebal core terhadap sifat bending komposit sandwich berpenguat serat sawit dengan core kayu 
sawit, Jurnal Sains Materi Indonesia, Vol. 8, No. 1, p.76-82.

Jones R.M., 1999, Mechanics of Composites

Materials, International Student Edition, Mc Graw-Hill ogakusha, Ltd.

Mahmuda E., Savetlana S., Sugiyanto, 2003, Pengaruh panjang serat terhadap kekuatan tarik komposit berpenguat serat ijuk dengan matrik epoxy, Jurnal FEMA, Vol. 1, No. 3, p.79-84.

Nuryanti, Salimy D.H., 2008, Metode permukaan respon dan aplikasinya pada optimasi eksperimen kimia, Risalah Lokakarya Komputasi Dalam Sains Dan Teknologi Nuklir, P. 373-391.

Prasetyo A.A., 2007, Analisa pengaruh fraksi volume serat aren (arenga pinata) dengan matrik polyester terhadap kekuatan bending dan tarik, Teknik Material Dan Metalurgi.

Pratama Y.Y., Setyanto R.H., Priadythama I., 2014, Pengaruh perlakuan alkali, fraksi volume serat dan panjang serat terhadap kekuatan tarik komposit serat sabut kelapa polyester, Jurnal IImiah Tekinik Industri, Vol. 13, No. 1, p. 8-15.

Sardia T., 2000, Pengetahuan Bahan Teknik, Pradnya Paramita, Jakarta.

Schwartz M.M., 1984, Composite Materials Handbook, McGraw-Hill Book Co., New York.

Surdia T., Saito S., 2000, Pengetahuan Bahan Teknik, Pradnya Paramita, Jakarta. 